\title{
HLA-B8, immunoglobulins, and antibody responses in alcohol-related liver disease
}

\author{
MARSHA Y MORGAN, MGR ROSS, CM NG, DM ADAMS, HC THOMAS, AND \\ SHEILA SHERLOCK
}

From the Departments of Medicine, Virology, Nephrology, and Haematology, The Royal Free Hospital, Pond Street, Hampstead, London NW3 2QG, UK

SUMMARY Ninety-two British, caucasian, alcoholic patients with liver disease were grouped on the basis of hepatic histology into fatty change, hepatitis with or without cirrhosis, and cirrhosis alone. Men with alcoholic hepatitis with or without cirrhosis showed an increased incidence of the histocompatibility antigen HLA-B8 $(P<0.02)$. Increased measles antibody titres were found in patients with cirrhosis with or without hepatitis and were associated with the B8 phenotype in both sexes. Rubella antibody titres and percentage DNA-binding were raised in patients with cirrhosis and showed no association with the B8 phenotype. Concentrations of 1 gM and $1 \mathrm{gA}$ were raised in patients with steatosis and with hepatitis, while in patients with cirrhosis IgG concentrations were also increased. Low titres of autoantibodies were found in all histological groups.

It is possible that the development of hepatitis in response to alcohol abuse may be influenced, at least in men, by a gene linked to the B locus. Otherwise, immune processes associated with alcoholrelated liver disease are probably secondary phenomena.

The liver damage seen in alcoholic subjects results from the direct hepatotoxic effect of ethanol. ${ }^{1}$ The development of alcoholic cirrhosis is often preceded by alcoholic hepatitis, ${ }^{2}$ although alcoholic cirrhosis may develop without the hepatitic stage. ${ }^{3}$

Only $20 \%$ of alcoholic subjects develop liver disease; therefore, constitutional or genetic factors may be concerned in this individual susceptibility to develop cirrhosis and may also influence the 'route' by which it develops.

The role of genetically determined immunological factors in the pathogenesis of alcohol-related liver disease has recently received much attention. Conflict has arisen, in particular, regarding the prevalence and importance of the histocompatibility antigen HLA-B8.4-8

We have therefore screened a group of 92 alcoholics with liver disease of varying severity for B8 in an attempt to clarify this situation. In addition, we have measured antibodies to rubella, measles, smooth muscle, nuclear and mitochondrial antigens, and serum immunoglobins for further evidence of an altered immune status in these patients. Particular attention has been paid to the relationship between these various indices and the histological changes on liver biopsy.

Received for publication 13 November 1979

\section{Patients and methods}

Ninety-two British, caucasian, alcoholic patients (68 men: 24 women) who had taken more than $100 \mathrm{~g}$ ethanol per day for at least five years were grouped, on the basis of liver histology, into fatty change only, alcoholic hepatitis with or without cirrhosis, or cirrhosis alone. All patients were abusing alcohol up to the time of hospitalisation, and liver biopsies were taken within one week of admission. Suitable investigations were undertaken to exclude other causes of liver disease.

HLA-B8 was detected by a microcytotoxicity technique. ${ }^{9}$ The control population consisted of 191 British caucasian patients who had suffered severe cerebral trauma and were being considered as potential kidney donors.

Rubella antibodies in the 92 alcoholics were measured by haemaglutination inhibition, measles antibodies by complement fixation, percentage DNA binding by a Farr technique using extrinsically labelled DNA,10 immunoglobulins by radial immunodiffusion, and the autoantibodies by indirect immunofluorescence. The control group comprised 27 British caucasian patients matched for age, sex, and socioeconomic group, none of whom had been immunised against rubella or measles. All were healthy, showing no clinical evidence of acute or 
chronic infection, and with normal liver function tests.

Viral titres were reduced to logarithm to base 2 and immunoglobulin concentrations to logarithm to base 10 for statistical analysis. Results from the alcoholics and control subjects were compared using Student's $t, 2 \times 2 \chi^{2}$, Wilcoxon rank pairs, and the Fisher exact probability tests. Results were calculated for the total population, for the histological subgroups, and for the male and female populations separately.

\section{Results}

Details of the 92 alcoholic patients are given in Table 1. The ages of the patients and the lengths of history of alcohol abuse were comparable in the three histological subgroups.

One woman with alcoholic hepatitis subsequently became hepatitis B surface antigen (HBsAg) positive. All other patients were $\mathrm{HBsAg}$ negative and no aetiology for their liver disease other than alcohol abuse was found.

HLA-B 8 (Table 2)

The incidence of $\mathrm{B} 8$ in the whole patient group, $26.4 \%(27 / 92)$, did not differ significantly from that of the control group, $22.5 \%(43 / 191)$. The incidence of B8 in the patients with fatty change, $31 \cdot 3 \%(10 / 32)$, and in the patients with cirrhosis alone, $12 \%(3 / 25)$, was similar to that of the controls. Patients with hepatitis \pm cirrhosis, however, showed an increased incidence, $40 \%(14 / 35)(P<0.05)$. The women did not show a significantly increased incidence of B8 in any of the histological subgroups. Men with hepatitis \pm cirrhosis showed an increased incidence of $\mathrm{B} 8$ of $50 \%(11 / 22)(\mathrm{P}<0.02)$. The increased incidence of $\mathrm{B} 8$ in the patients with hepatitis \pm cirrhosis results therefore from an increased incidence of this phenotype in the male subjects.

VIRAL ANTIBOdies (Table 3)

\section{(a) Rubella}

The mean rubella antibody titre in the whole patient group was similar to the control mean. The alcoholics with cirrhosis alone showed a significantly increased mean antibody titre $(P<0.005)$. There were no significant differences in mean antibody titre in the men and women or in the $\mathrm{B} 8$ positive and negative populations.

\section{(b) Measles}

The mean measles antibody titre was significantly

Table 1 Details of 92 patients with alcohol-related liver disease

\begin{tabular}{|c|c|c|c|c|c|}
\hline Patient group & Total No. & Men & Women & $\begin{array}{l}\text { Mean age } \pm I S D \\
y r\end{array}$ & $\begin{array}{l}\text { Length of alcohol } \\
\text { history } \pm I S D \\
y r\end{array}$ \\
\hline $\begin{array}{l}\text { All patients } \\
\text { Fatty change only } \\
\text { Alcoholic hepatitis } \pm \\
\text { cirrhosis } \\
\text { Cirrhosis alone }\end{array}$ & $\begin{array}{l}92 \\
32 \\
\\
35 \\
25\end{array}$ & $\begin{array}{l}68 \\
27\end{array}$ & $\begin{array}{r}24 \\
5\end{array}$ & $\begin{array}{l}50.0 \pm 9.9 \\
46.1 \pm 8.9 \\
50.1 \pm 10.1 \\
55.0 \pm 8.8\end{array}$ & $\begin{array}{l}19.7 \pm 10.0 \\
16.5 \pm 9.3 \\
20 \cdot 1 \pm 10.5 \\
23.0 \pm 9.1\end{array}$ \\
\hline
\end{tabular}

Table 2 Incidence of B8 phenotype in patients with alcohol-related liver disease and control subjects

\begin{tabular}{|c|c|c|c|}
\hline \multirow[t]{2}{*}{ Population and histological subgroups } & \multicolumn{2}{|c|}{$H L A B 8$ positive } & \multirow[t]{2}{*}{ Significance fro $m$ control (P value } \\
\hline & $\%$ & No. & \\
\hline Control subjects & $22 \cdot 5$ & $43 / 191$ & \\
\hline $\begin{array}{ll}\text { Alcoholics } & \text { Total } \\
& \text { Men } \\
& \text { Women }\end{array}$ & $\begin{array}{l}29 \cdot 4 \\
27 \cdot 9 \\
33 \cdot 3\end{array}$ & $\begin{array}{r}27 / 92 \\
19 / 68 \\
8 / 24\end{array}$ & $\begin{array}{l}\text { NS } \\
\text { NS } \\
\text { NS }\end{array}$ \\
\hline $\begin{array}{ll}\text { Fatty change only } & \begin{array}{l}\text { Total } \\
\text { Men } \\
\text { Women }\end{array}\end{array}$ & $\begin{array}{l}31 \cdot 3 \\
25 \cdot 9 \\
60 \cdot 0\end{array}$ & $\begin{array}{c}10 / 32 \\
7 / 27 \\
3 / 5\end{array}$ & $\begin{array}{l}\text { NS } \\
\text { NS } \\
\text { NS }\end{array}$ \\
\hline $\begin{array}{ll}\text { Hepatitis } \pm \text { cirrhosis } & \begin{array}{l}\text { Total } \\
\text { Men } \\
\text { Women }\end{array}\end{array}$ & $\begin{array}{l}40 \cdot 0 \\
50 \cdot 0 \\
23 \cdot 0\end{array}$ & $\begin{array}{r}14 / 35 \\
11 / 22 \\
3 / 13\end{array}$ & $\begin{array}{l}<0.05 \\
<0.02 \\
\text { NS }\end{array}$ \\
\hline $\begin{array}{ll}\text { Cirrhosis alone } & \text { Total } \\
& \text { Men } \\
& \text { Women }\end{array}$ & $\begin{array}{r}12 \cdot 0 \\
5 \cdot 3 \\
33 \cdot 3\end{array}$ & $\begin{array}{l}3 / 25 \\
1 / 19 \\
2 / 6\end{array}$ & $\begin{array}{l}\text { NS } \\
\text { NS } \\
\text { NS }\end{array}$ \\
\hline
\end{tabular}

P value $2 \times 2 x^{2}$ or Fisher exact probability.

NS $=$ not significant. 
increased in the whole patient group compared with the control mean $(P<0.025)$. Alcoholics with fatty change only had a normal mean titre, but significant increases in mean antibody titre were seen in patients with hepatitis \pm cirrhosis $(\mathrm{P}<0.02)$ and with cirrhosis alone $(\mathrm{P}<0.01)$.

In the patient group as a whole, the men showed raised measles antibody titres irrespective of their B8 phenotype, whereas raised titres in the women were related to the presence of the B8 phenotype. In patients with cirrhosis \pm hepatitis, increased measles antibody titres were associated with the B8 phenotype in both sexes.

\section{DNA BINDING}

In control subjects the percentage DNA binding was $20-32 \%$. The mean percentage binding for the whole patient group $\pm 1 \mathrm{SD}, 37 \cdot 8 \pm 9 \cdot 1$, was not significantly different from normal. Patients with fatty change only had a mean percentage binding of $33.4 \pm 3.1$ and those with hepatitis \pm cirrhosis $35 \cdot 3 \pm 8 \cdot 0$. Patients with cirrhosis alone had a significantly increased mean percentage binding, $46.6 \pm 9.7(\mathrm{P}<0.01)$.

IMMUNOGLOBULINS (Table 4)

Overall the alcoholic patients showed significantly increased mean concentrations for all three immunoglobulins compared with the control subjects: IgG (P < 0.01), IgM ( $P<0.001), \operatorname{IgA}(\mathrm{P}<0.001)$. Patients with fatty change only showed significantly increased concentrations of $\operatorname{IgM}(\mathrm{P}<0.01)$ and $\operatorname{IgA}$ $(\mathrm{P}<0.005)$.

Similar changes were seen in the alcoholic patients with hepatitis alone. In the patients with hepatitis and cirrhosis and in those with cirrhosis alone, significant increases were seen in all three immunoglobulin classes.

\section{AUtoantibodies (Table 5)}

At least one positive test was found in $18.5 \%$ $(17 / 92)$ of the alcoholic patients. Autoantibodies were present in low titre, either $1 / 10$ or $1 / 40$. Numbers were too small for statistical analysis.

Table 5 Incidence of autoantibodies in patients with alcohol-related liver disease

\begin{tabular}{|c|c|c|c|}
\hline Patient group & $\begin{array}{l}S M A \\
(\% \text { positive })\end{array}$ & $\begin{array}{l}\text { ANF } \\
(\% \text { positive })\end{array}$ & $\begin{array}{l}A M A \\
(\% \text { positive })\end{array}$ \\
\hline All patients & $8 \cdot 7(8 / 92)$ & $10.9(10 / 92)$ & $1 \cdot 1(1 / 92)$ \\
\hline Fatty change only & $6 \cdot 3(2 / 32)$ & $3 \cdot 1 \quad(1 / 32)$ & $3 \cdot 1(1 / 32)$ \\
\hline $\begin{array}{l}\text { Hepatitis } \pm \\
\text { cirrhosis } \\
\text { Cirrhosis alone }\end{array}$ & $\begin{array}{r}8.6(3 / 35) \\
12.0(3 / 25)\end{array}$ & $\begin{array}{ll}17 \cdot 2 & (6 / 35) \\
12 \cdot 0 & (3 / 25)\end{array}$ & $\begin{array}{l}0 \\
0\end{array}$ \\
\hline
\end{tabular}

SMA = smooth muscle antibody; ANF = antinuclear factor; AMA $=$ mitochondrial antibody.

\section{Discussion}

In this population of 92 British alcoholics the incidence of $\mathrm{B} 8$ was normal. However, the men with alcoholic hepatitis showed an increased incidence of

Table 3 Viral antibody titres in patients with alcohol-related liver disease and control subjects

\begin{tabular}{|c|c|c|c|c|}
\hline Patient group & $\begin{array}{l}\text { Rubella antibody titre* } \\
(\text { Mean } \pm I S D)\end{array}$ & $\begin{array}{l}\text { Significance from control } \\
(\mathrm{P} \dagger \text { value })\end{array}$ & $\begin{array}{l}\text { Measles antibody titre } \\
(\text { Mean } \pm I S D)\end{array}$ & $\begin{array}{l}\text { Significance from control } \\
\text { (P value) }\end{array}$ \\
\hline $\begin{array}{l}\text { Control subjects } \\
\text { All patients } \\
\text { Fatty change only } \\
\text { Hepatitis } \pm \text { cirrhosis } \\
\text { Cirrhosis alone }\end{array}$ & $\begin{array}{l}5.9 \pm 1.9 \\
6.4 \pm 1.9 \\
5.9 \pm 1.7 \\
5.8 \pm 1.7 \\
7.7 \pm 1.9\end{array}$ & $\begin{array}{l}\text { NS } \\
\text { NS } \\
\text { NS } \\
<0.005\end{array}$ & $\begin{array}{l}3.3 \pm 0.6 \\
4 \cdot 1 \pm 1.4 \\
3.5 \pm 1 \cdot 2 \\
4.3 \pm 1.6 \\
4.4 \pm 1.6\end{array}$ & $\begin{array}{l}<0.025 \\
\text { NS } \\
<0.02 \\
<0.01\end{array}$ \\
\hline
\end{tabular}

*Titre refers to logarithm to base 2 of the reciprocal dilution.

$\dagger P$ value Student's $t$ test.

NS $=$ not significant.

Table 4 Immunoglobulin concentrations in patients with alcohol-related liver disease and control subjects

\begin{tabular}{|c|c|c|c|c|c|c|}
\hline Patient group & $\begin{array}{l}\text { IgG concentration } \\
(M e a n \pm I S D) g / l\end{array}$ & $\begin{array}{l}\text { Significance from } \\
\text { controls }\left(\mathrm{P}^{*} \text { value }\right)\end{array}$ & $\begin{array}{l}\text { IgM concentration } \\
(M e a n \pm I S D) g / l\end{array}$ & $\begin{array}{l}\text { Significance from } \\
\text { controls (P value) }\end{array}$ & $\begin{array}{l}\text { IgA concentration } \\
(M e a n \pm 1 S D) g / l\end{array}$ & $\begin{array}{l}\text { Significance from } \\
\text { controls (P value) }\end{array}$ \\
\hline $\begin{array}{l}\text { Control subjects } \\
\text { All patients } \\
\text { Fatty change only } \\
\text { Hepatitis } \pm \text { cirrhosis } \\
\text { Cirrhosis alone }\end{array}$ & $\begin{array}{l}11.5 \pm 2.5 \\
14.4 \pm 4.7 \\
13.0 \pm 2.5 \\
13.4 \pm 4.3 \\
17.5 \pm 6.0\end{array}$ & $\begin{array}{l}<0.01 \\
\text { NS } \\
\text { NS } \\
<0.005\end{array}$ & $\begin{array}{l}1 \cdot 0 \pm 0.6 \\
2 \cdot 2 \pm 2 \cdot 1 \\
1.6 \pm 0.8 \\
2 \cdot 5 \pm 3 \cdot 2 \\
2 \cdot 2 \pm 1 \cdot 2\end{array}$ & $\begin{array}{l}<0.001 \\
<0.01 \\
<0.001 \\
<0.001\end{array}$ & $\begin{array}{l}2.0 \pm 0.9 \\
4.9 \pm 2.8 \\
3.6 \pm 1.2 \\
4.9 \pm 2.5 \\
6.4 \pm 3.8\end{array}$ & $\begin{array}{l}<0.001 \\
<0.005 \\
<0.001 \\
<0.001\end{array}$ \\
\hline
\end{tabular}

*Student's $t$ test.

NS $=$ not significant. 
this antigen. The association between various histocompatibility antigens and alcoholic liver disease has been studied before. ${ }^{4-8}$ Freudenberg et al. ${ }^{4}$ and Scott et al. ${ }^{6}$ showed a normal distribution of histocompatibility antigens in patients with alcoholic cirrhosis. Bailey et al. ${ }^{5}$ showed that B8 was more prevalent in a group of 53 British alcoholics with cirrhosis \pm alcoholic hepatitis than in control subjects but showed a normal incidence in 10 alcoholics with fatty change and minimal fibrosis on liver biopsy. These workers also commented on the absence of HLA-A28 in their cirrhotic group. Bell and Nordhagen ${ }^{7}$ reported a normal incidence of B8 but an increased incidence of HLA-BW40 in 25 Norwegian alcoholics with cirrhosis \pm hepatitis. This particular antigen was not tested by the previous workers. ${ }^{4-6}$ The possible absence of A28 was also commented upon. More recently, Meléndez et al. ${ }^{8}$ from Chile reported an increased incidence of HLA-B13 in a group of 40 alcoholic cirrhotics but a normal incidence of this antigen in alcoholics without cirrhosis. Normal frequencies had been reported for this antigen by other workers. ${ }^{6}$ The Chilean workers found normal incidences for B8 and BW40 in their patients but had not tested for A28. Thus, while certain of these reports have shown some association between alcohol-related liver disease and one or other of the B locus alleles, no consistent association with a particular HLA phenotype has been found. In none of these previous studies was an attempt made to analyse the incidence of the various antigens in patients with and without alcoholic hepatitis when a more definitive association might have been found.

The broad implication is that in certain patients the genetic factor responsible for the predisposition to develop liver disease, in particular hepatitis, in response to alcohol abuse is in dysequilibrium with the $B$ locus determinants. The $B$ locus antigen involved may be different in each gene pool. Family studies would be needed to determine whether the predisposition to develop florid hepatitis in response to alcohol abuse is inherited and whether the inheritance is linked with the B locus alleles.

Increased antibody titres to measles were found in the patients with hepatitis \pm cirrhosis and in those with cirrhosis alone, and there was, in addition, an association between these increased titres and the B8 phenotype. This suggests that the immune response to this virus is related to the presence of B8 and to the presence of liver damage, but is not specifically related to the development of alcoholic hepatitis. This is supported by the finding of a similar increase in measles antibody titres in HBsAg positive chronic active hepatitis. ${ }^{11}$ The increase in measles antibody titres in these two diseases is much smaller than in $\mathrm{HBsAg}$ negative chronic active hepatitis. ${ }^{11}$

The increased antibody titres to rubella seen in our patients with cirrhosis alone and reported in other forms of chronic liver disease by Triger et al. ${ }^{12}$ are presumably related to severe liver injury but not to the $\mathrm{B} 8$ phenotype.

The increase in DNA binding in the patients with cirrhosis also appears to be related to liver injury, confirming previous observations. ${ }^{13}$

The increases in IgM and IgA concentrations accompanying steatosis and hepatitis might represent a local immune response in the lamina propria of the small intestine, perhaps related to changes in the mucosal permeability induced by alcohol. ${ }^{14}$ The rise in IgG concentration which accompanied cirrhosis in our alcoholic patients is also seen in patients with cirrhosis of other aetiologies ${ }^{15}$ and in animals with chemically induced cirrhosis; ${ }^{16}$ it probably reflects failure of the liver to sequester antigen. ${ }^{17}$

Low titre nuclear and smooth muscle antibodies were demonstrated in patients with all types of alcohol-related liver injury. Similar low titres are found in other forms of chronic liver injury and in animals with chemically induced cirrhosis. ${ }^{16}$ The autoantibody titres in our patients were much lower than in those in $\mathrm{HBsAg}$ negative chronic active hepatitis, and their presence appears to be a consequence of liver injury. ${ }^{16}$ The incidence of autoantibodies in patients with alcohol-related liver disease found in this study is similar to that found by Bailey et al. ${ }^{5}$

In summary, we have shown an increased incidence of B8 in men with alcoholic hepatitis, which suggests that the susceptibility to develop this particular liver lesion in men involves genetic factors. Raised measles antibodies were present in similar titre to those found in $\mathrm{HBsAg}$ positive chronic active hepatitis, which suggests that they merely serve as a reflection of liver injury. Increases in immunoglobulins may reflect changes in small intestinal wall permeability and failure of the liver to sequester antigens.

HCT is supported by the Wellcome Trust.

\section{References}

${ }^{1}$ Lieber CS. Liver disease and alcohol: fatty liver, alcoholic hepatitis, cirrhosis and their interrelationships. Ann NY Acad Sci 1975;252:63-84.

2 Gerber MA, Popper H. Relationship between central canals and portal tracts in alcoholic hepatitis: a contribution to the pathogenesis of cirrhosis in alcoholics. Hum Pathol 1972;3:199-207.

${ }^{3}$ Popper H. The pathogenesis of alcoholic cirrhosis. In: 
Fisher MM, Rankin JG, eds. Alcohol and the Liver. New York: Plenum Press, 1977:289-306.

${ }^{4}$ Freudenberg J, Erdmann K, Meyer zum Büschenfelde K-H, Förster E, Berger J. HL-A bei Lebereerkrankungen. Klin Wochenschr 1973;51:1075-6.

${ }^{5}$ Bailey RJ, Krasner N, Eddlestone ALWF, et al. Histocompatibility antigens, auto-antibodies and immunoglobulins in alcoholic liver disease. $\mathrm{Br} \mathrm{Med} \mathrm{J}$ 1976;2:727-9.

${ }^{6}$ Scott BB, Rajah SM, Losowsky MS. Histocompatibility antigens in chronic liver disease. Gastroenterology 1977;72:122-5.

${ }^{7}$ Bell H, Nordhagen R. Association between HLABW40 and alcoholic liver disease with cirrhosis. Br Med J 1978;1:822.

${ }^{8}$ Meléndez M, Vargas-Tank L, Fuentes $\mathrm{C}$, et al. Distribution of HLA histocompatibility antigens, ABO blood groups and $\mathrm{Rh}$ antigens in alcoholic liver disease. Gut 1979;20:288-90.

${ }^{\circ}$ Batchelor JR. Assays for cytotoxic and haemagglutinating antibodies against histocompatibility antigens. In: Weir DM, ed. Handbook of Experimental Immunology. 2nd ed. Oxford: Blackwell, 1973:32.

10 Wold RT, Young FE, Tan EM, Farr RS. Deoxyribonucleic acid antibody: a method to detect its primary interaction with deoxyribonucleic acid. Science 1968;161:806-7.

11 Crimmins FB, Adams DM, Ross MGR, Ash G,
Thomas HC, Sherlock S. Viral antibody titres in HBs antigen positive and negative chronic active hepatitis. Scand J Gastroenterol 1980; in press.

12 Triger DR, Kurtz JB, Wright R. Viral antibodies and autoantibodies in chronic liver disease. Gut 1974;15: 94-8.

${ }^{13}$ Jain S, Markham R, Thomas HC, Sherlock S. Doublestranded DNA-binding capacity of serum in acute and chronic liver disease. Clin Exp Immunol 1976; 26:35-41.

${ }^{14}$ Krasner N, Cochran KM, Russell RI, Carmichael HA, Thompson GG. Alcohol and absorption from the small intestine. I. Impairment of absorption from the small intestine in alcoholics. Gut 1976;17:245-8.

${ }^{15}$ Feizi T. Immunoglobulins in chronic liver disease. Gut 1968;9:193-8.

${ }^{16}$ McSween RNM, Thomas HC, Tilney LN, Horne CHM. Cell-mediated and humoral immunity in a rat experimental model. In: Leevy CM, ed. Diseases of the Liver and Biliary Tract. Basle: S Karger, 1976:23-6.

17 Thomas HC, McSween RNM, White RG. Role of the liver in controlling the immunogenicity of commensal bacteria in the gut. Lancet 1973;1:1288-91.

Requests for reprints to: Dr MY Morgan, Medical Unit, Royal Free Hospital, Pond Street, Hampstead, London NW3 2QG, UK. 